\title{
Assessment of atmospheric pollution with heavy metals and nitrogen using Pleurozium schreberi mosses as bioindicator in Latvia: spatial and temporal aspects
}

\author{
Guntis Tabors $^{1 *}$, Oḷgerts Nikodemus ${ }^{2}$, Linda Dobkeviča² ${ }^{2}$ Laura Kḷavina ${ }^{2}$, Anna Ajanoviča ${ }^{2}$, \\ Konstantīns Viligurs² ${ }^{2}$ Imants Krūze ${ }^{2}$
}

\author{
${ }^{1}$ Department of Botany and Ecology, Faculty of Biology, University of Latvia, Jelgavas 1, Riga LV-1004, Latvia \\ ${ }^{2}$ Department of Environmental Science, Faculty of Geography and Earth Sciences, University of Latvia, Jelgavas 1, Riga LV-1004, \\ Latvia \\ ${ }^{\star}$ Corresponding author, E-mail: guntis.tabors@lu.lv
}

\begin{abstract}
Concentrations of eight metals $(\mathrm{Cd}, \mathrm{Cr}, \mathrm{Cu}, \mathrm{Fe}, \mathrm{Ni}, \mathrm{Pb}, \mathrm{Zn}$ and $\mathrm{V})$ and nitrogen were determined during a nation-wide biomonitoring survey using Pleurozium schreberi moss in Latvia. Particular concentrations of heavy metals were clearly associated with local emission point sources in Liepāja (Cd, $\mathrm{Cr}, \mathrm{Cu}, \mathrm{Fe}, \mathrm{Pb}, \mathrm{V}, \mathrm{Zn})$, Brocēni $(\mathrm{Ni})$, Riga (Cr, Cu) and Daugavpils $(\mathrm{Cr}, \mathrm{Cu}, \mathrm{Fe}, \mathrm{Ni}, \mathrm{Zn})$. Increased concentrations in the western part of Latvia $(\mathrm{Cd}, \mathrm{Cr}, \mathrm{Cu}, \mathrm{Ni}, \mathrm{Pb}, \mathrm{V}, \mathrm{Zn})$ were due to the long-range transboundary transport of pollution from Europe and local metallurgical and other factories sources in Liepāja City. Higher concentrations near the Lithuanian border were associated with the impact of pollution from the cement industry of Naujoji Akmene ( $\mathrm{Cu}, \mathrm{Fe}, \mathrm{Ni})$ and the oil refinery of Mažeikiai (Ni, V). In general, concentrations of heavy metals were lower in Latvia compared to the background levels in Europe. In comparison to the previous monitoring results, the concentration of heavy metals in moss has decreased in Latvia. The higher $\mathrm{N}$ concentrations in the south-western part of Latvia were due to the long-range transboundary transport of pollution, territories with intensive agriculture and areas close to the industrial cities.
\end{abstract}

Key words: air pollution, biomonitoring, heavy metals, Latvia, moss, nitrogen.

\section{Introduction}

Biomonitoring is a technique for using organisms to determine air quality change and pollution distribution. Moss is an inexpensive and effective material that accumulates atmospheric and environmental pollution deposits and, therefore, is particularly suitable for the analysis and identification of areas with high atmospheric deposition fluxes and temporal trends (Harmens et al. 2010). The recommended moss species for biomonitoring in Europe are Hylocomium splendens, Pleurozium schreberi (Ross 1990; Poikolainen et al. 2004; Kosior et al. 2010), Hypnum cupressiforme (González-Miqueo et al. 2010) and Pseudoscleropodium purum (Boquete et al. 2014). Mosses have been shown to be suitable as indicators of atmospheric deposition with heavy metals (Rühling, Tyler 1973; Rinne, Mäkinen 1988; Brūmelis, Nikodemus 1995; Nikodemus, Brūmelis 1998; Kayee et al. 2015), nitrogen (GonzálezMiqueo et al. 2010; Harmens et al. 2011; Harmens et al. 2014) and persistent organic pollutants (Gałuszka 2007; Migaszewski et al. 2009; Dolegowska, Migaszewski 2011).

The moss biomonitoring method has been applied at international (Harmens et al. 2008; Harmens et al. 2013;
Harmens et al. 2015), regional (Rühling, Tyler 1973; Markert et al. 1996; Čeburnis et al. 1999; Gerdol et al. 2000; Nikodemus et al. 2004; Salemaa et al. 2004; Sucharová, Suchara 2004; Zechmeister et al. 2008; Šakalys et al. 2009; Kösta, Liiv 2011) and local scales (Brūmelis, Nikodemus 1993; Nikodemus, Brūmelis 1993; Brūmelis et al. 1999; Genoni et al. 2000).

The aim of the present study was to perform a nationwide survey on the current situation in Latvia in respect to pollution with heavy metals and nitrogen using feather moss Pleurozium schreberi and to compare the obtained data with the previous biomonitoring results.

\section{Materials and methods}

\section{Moss sampling}

Biomonitoring of atmospheric heavy metal distributions has been conducted using moss in five national surveys: in 1990, using Hylocomium splendens collected in 81 plots; and in 1995, 2000, 2005 and 2015, using Pleurozium schreberi in 101 plots (Fig. 1). Change from one species to the other was made because P. schreberi has wider distribution in Latvia. Compared with 1990, when moss was collected from pine, 
spruce or mixed forests, sampling in the subsequent years was made in dominant pine stands. The sampling sites in 2015 had close locations to those in 1990. Each sampling plot was located at least $300 \mathrm{~m}$ from major roads and at least $1 \mathrm{~km}$ from pollution point sources and from large cities; the plot size was $50 \times 50 \mathrm{~m}$. Carpet-forming bryophytes, bilberry (Vaccinium myrtillus) and lingonberry (Vaccinium vitis-idaea) dominated in the understorey. Moss sampling period was from middle August to middle October 2015.

\section{Analytical methods}

The analysis was carried out at the University of Latvia. Moss samples were dried at room temperature for about a week and then at $40{ }^{\circ} \mathrm{C}$ for $24 \mathrm{~h}$, and cleaned from coniferous needles, leaves and other debris. Only green parts of the moss material were used for the analyses. All methods, including moss sampling and heavy metals analysis, were performed according to standardized methods (ICP Vegetation 2010).

Concentrations of eight metals $(\mathrm{Cd}, \mathrm{Cr}, \mathrm{Cu}, \mathrm{Fe}, \mathrm{Ni}, \mathrm{Pb}$, $\mathrm{Zn}$ and $\mathrm{V}$ ) were measured using an atomic absorption spectrophotometer (AAnalyst 800, Perkin-Elmer). The modified Kjeldal method was used for the determination of nitrogen.

Quality control of the analytical process was conducted (Steinnes et al.1997; Harmens et al.2008). The moss reference materials M2, containing elevated concentrations of most metals, and M3, containing background concentrations of most metals, were obtained from the Coordination Centre of the International Cooperative Programme on Effects of Air Pollution on Natural Vegetation and Crops, Centre for Ecology \& Hydrology, Bangor, UK.

\section{Data analysis and mapping}

Microsoft Excel was used for data entry and statistical analysis. Mapping was conducted using ArcView.

\section{Results}

\section{Cadmium}

Cadmium concentration in P. schreberi moss in Latvia was low (Table 1). The highest $\mathrm{Cd}$ concentration $\left(0.55 \mathrm{mg} \mathrm{kg}^{-1}\right)$ was found in the western part of Latvia (Fig. 2A), around Liepāja.

\section{Chromium}

Due to the relatively slow development of industry, high Cr concentration (Table 1) was not characteristic in Latvia. Slightly increased $\mathrm{Cr}$ concentration $\left(0.86 \mathrm{mg} \mathrm{kg}^{-1}\right)$ in moss was found in the western part of Latvia, around Liepāja, and this might be related to the previously mentioned factors. Slightly increased $\mathrm{Cr}$ concentration was also found around the largest cities of Latvia: Riga, Jelgava and Daugavpils (Fig. 2B).

\section{Copper}

Similarly to other elements, the highest $\mathrm{Cu}$ concentration in P. schreberi moss in 2015 was also found in the western part of Latvia (Fig. 2C). While the median $\mathrm{Cu}$ concentration in moss in Latvia was $5.17 \mathrm{mg} \mathrm{kg}^{-1}$ (Table 1), the $\mathrm{Cu}$ concentration in the moss collected in the western part of Latvia around Skrunda and Liepāja reached 8.95 to 12.21 $\mathrm{mg} \mathrm{kg}{ }^{-1}$. Another separate area of $\mathrm{Cu}$ pollution distribution had formed in the eastern part of Latvia, around Daugavpils and Rēzekne, where the concentration of $\mathrm{Cu}$ reached 7.01

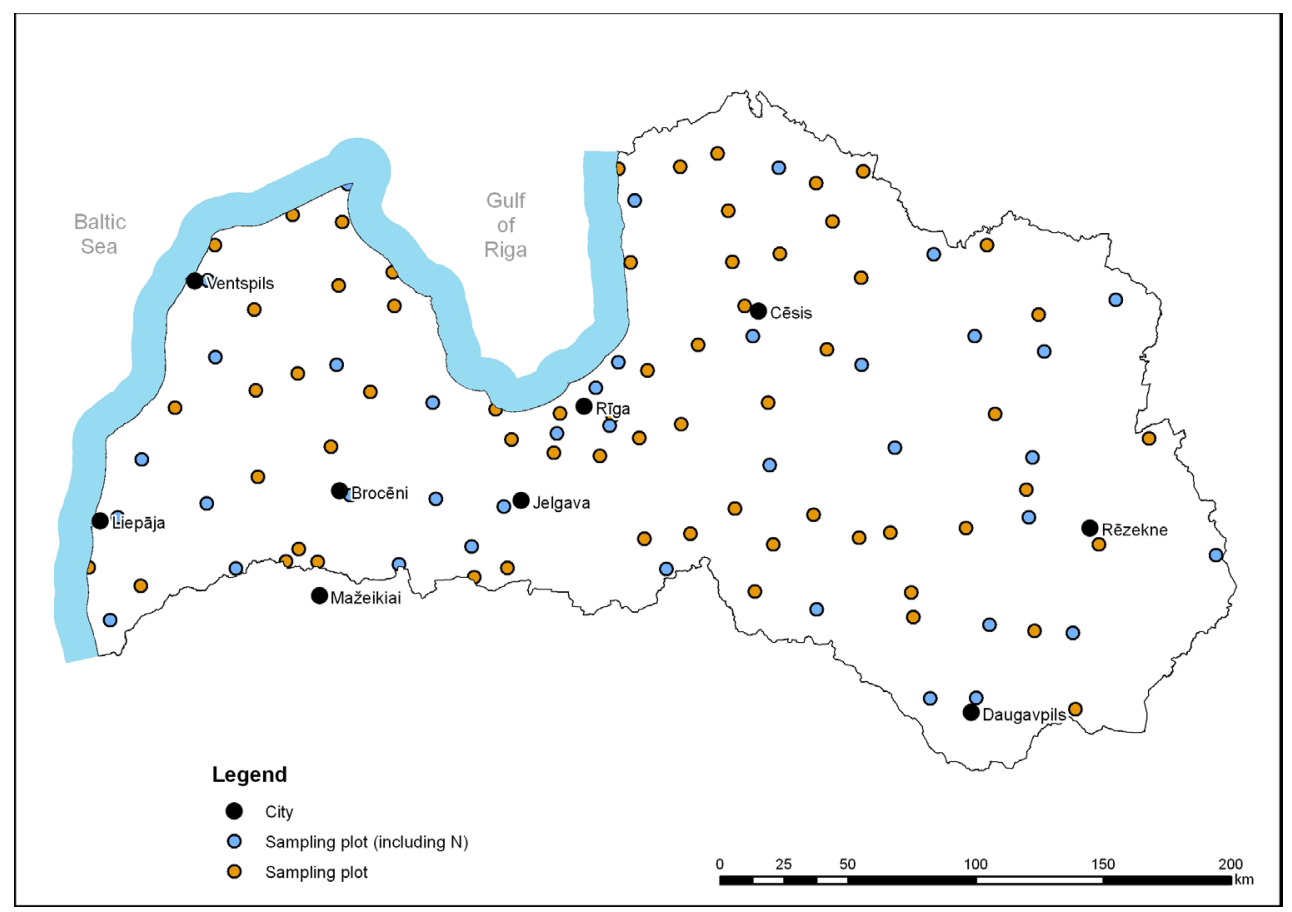

Fig. 1. Location of sampling plots in Latvia in 2015; the major cities are also shown. 
Table 1. Minimum, maximum and median concentrations of heavy metals ( $\left.\mathrm{mg} \mathrm{kg}^{-1}\right)$ and nitrogen (\%) in Pleurozium schreberi moss in Latvia in 2015 and the median concentration in Europe in 2010 (Harmens et al. 2013)

$\begin{array}{lcccccccccc} & \mathbf{V} & \mathbf{C r} & \mathbf{N i} & \mathbf{C d} & \mathbf{P b} & \mathbf{Z n} & \mathbf{C u} & \mathbf{F e} & \mathbf{N} \\ \text { Minimum } & 0.17 & 0.01 & 0.20 & 0.04 & 0.41 & 22.40 & 2.37 & 36.91 & 0.75 \\ \text { Maximum } & 2.54 & 1.04 & 1.67 & 0.55 & 9.20 & 99.79 & 12.31 & 587.82 & 1.83 \\ \text { Median } & 0.49 & 0.33 & 0.48 & 0.10 & 1.26 & 33.13 & 5.17 & 133.02 & 1.13 \\ \text { Europe } & 1.72 & 1.82 & 1.94 & 0.20 & 3.57 & 31.00 & 6.53 & 538.00 & 1.19\end{array}$

and $8.18 \mathrm{mg} \mathrm{kg}^{-1}$ respectively; as well as around Riga (in Beberbeki), with the concentration of $12.31 \mathrm{mg} \mathrm{kg}^{-1}$.

Iron

The highest Fe concentration (329.37 to $587.82 \mathrm{mg} \mathrm{kg}^{-1}$ ) in moss was found near the largest cities of western Latvia (Liepāja, Ventspils) (Fig. 2D). At the same time, attention must be drawn to the slightly increased Fe concentration around the cement industry in Brocēni (Latvia; $323.49 \mathrm{mg}$ $\mathrm{kg}^{-1}$ ) and Naujoji Akmene (Lithuania; $183.79 \mathrm{mg} \mathrm{kg}^{-1}$ ).

\section{Nickel}

In 2015, an increased Ni concentration in P. schreberi moss in Latvia was found in small local areas (Fig. 2E). Relatively higher Ni concentration ( 0.97 to $1.64 \mathrm{mg} \mathrm{kg}^{-1}$ ) was found in the southern part of Latvia, near the Lithuanian border. Here, the Ni concentration in P. schreberi moss was due to the long-range transport of pollution from the Mažeikiai Nafta oil refinery industry and the Naujoji Akmene cement industry. The increased Ni concentration around Brocēni was related to pollution emissions from the Brocēni cement industry.

Higher Ni concentration in moss was also found near other largest cities of Latvia, for example, Liepāja (Grobina plot, $1.00 \mathrm{mg} \mathrm{kg}^{-1}$ ) and Daugavpils (Daugavpils, $0.86 \mathrm{mg}$ kg-1; and Ilūkste, $1.06 \mathrm{mg} \mathrm{kg}^{-1}$ ).

\section{Lead}

The highest lead concentration in P. schreberi moss in 2015 was found in the western part of Latvia, near Liepāja (9.20 $\mathrm{mg} \mathrm{kg}^{-1}$; Fig. 2F). Higher $\mathrm{Pb}$ concentration in moss was found near Kārsava $\left(3.62 \mathrm{mg} \mathrm{kg}^{-1}\right)$, in the eastern part of Latvia, not far from the border with Russia.

\section{Vanadium}

Pollution with vanadium had a local character (Fig. 2G) in Latvia with an explicit decreasing tendency in the westeast direction. The highest $\mathrm{V}$ concentration in $P$. schreberi moss in 2015 was detected in the southern part of Latvia, near the Lithuanian border (1.42 to $2.54 \mathrm{mg} \mathrm{kg}^{-1}$ ). Higher V concentration in moss was found near other largest cities: Liepāja (Grobin, $1.36 \mathrm{mg} \mathrm{kg}^{-1}$; and Bārta, $1.29 \mathrm{mg} \mathrm{kg}^{-1}$ ) and Ventspils (1.24 $\mathrm{mg} \mathrm{kg}^{-1}$ ).

Zinc

A relatively high zinc concentration in P. schreberi moss was found in a small area in Latvia in 2015 (Fig. 2H). For a long time, the main source of $\mathrm{Zn}$ pollution in Latvia has been the Liepāja metallurgical industry (48.37 to $99.79 \mathrm{mg} \mathrm{kg}^{-1}$ ).

\section{Nitrogen}

The highest $\mathrm{N}$ concentration in P. schreberi moss in 2015 was identified in the south-western part of Latvia (1.74 to $1.83 \%)$, and the lowest $(<1.10 \%)$ in the northern part (Fig. 3).

\section{Retrospective analysis of heavy metal concentrations in moss}

The mapping of distribution of heavy metal pollution in Latvia using moss was performed in 1990, 1995, 2000, 2005 and 2015. Therefore, it is possible to compare these data retrospectively.

It must be mentioned that the economic situation changed significantly over this period in Latvia. When the national monitoring was started in 1990, many post-soviet industries and thermal power plants were still operating, and traffic was not intensive and mostly consisted of cars manufactured in the Soviet Union. If initially industries operated at full capacity, by 1995 many industries had already been shut down or their manufacturing intensity has greatly decreased. This is also confirmed by the fact that the concentrations of all heavy metals had decreased by 2015 in comparison to the results of 1995 (Fig. 4).

Comparison of the concentrations of all heavy metals with the average European indicators showed that the pollution level in Latvia corresponds with that in Europe, as seen by the results summarised in Table 1 . Table shows that the medians of all elements, except $\mathrm{Zn}$, are lower in Latvia than the average calculated median in Europe. The concentration medians of all metals are $50 \%$ or lower than in Europe, except Zn, which is slightly higher (6.4 \%).

Vanadium, chromium and nickel concentrations decreased consistently in every moss sample analysis period. Cadmium concentration levels also decreased since 1990 , with an exception in 2005, when it was increased. Fig. 4 shows that pollution has decreased since 1990. However, during the last three mapping surveys of heavy metal distribution (2000, 2005 and 2015), the concentration of $\mathrm{Cu}$ has become stable and no concentration decrease tendency has been observed. A similar situation can be observed with $\mathrm{Pb}$, as its concentration in moss has not decreased significantly since 2000. Further, in comparison with 1990 , 

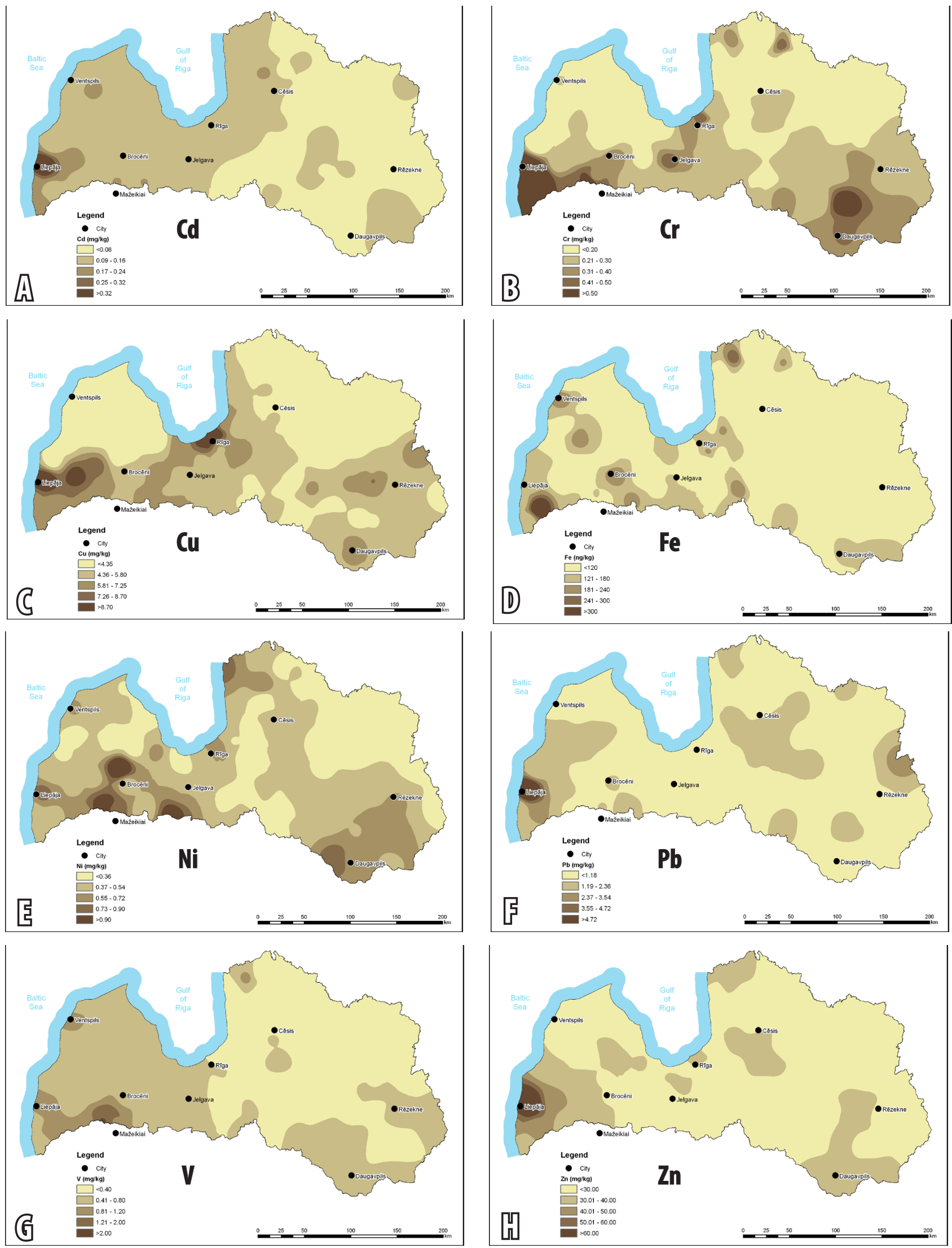

Fig. 2. Heavy metal Cd (A), Cr (B), Cu (C), Fe (D), Ni (E), Pb (F), V (G), Zn(H) concentrations (mg kg-1) in moss Pleurozium schreberi in Latvia in 2015. 


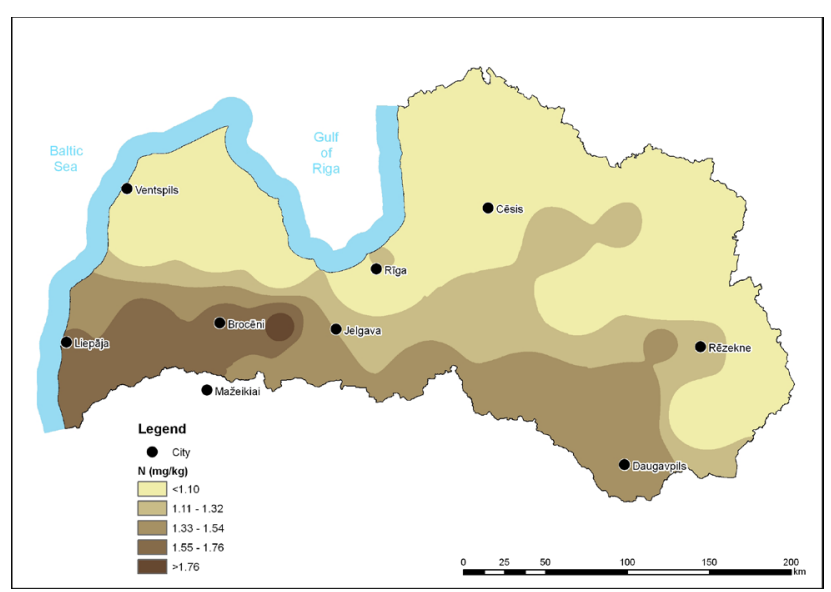

Fig. 3. Nitrogen concentration (\%) in moss Pleurozium schreberi in Latvia in 2015.

the data of 2015 show a decrease in $\mathrm{Zn}$ concentration. However, the data from 1995 through 2000 (Fig. 4) reveal an unchanged concentration over this period. Next, the overall $\mathrm{Fe}$ concentrations in Latvia have decreased since
1995, while there have been no radical concentration shift since 2000 (Fig. 4).

\section{Discussion}

In Latvia the overall concentrations of heavy metals in mosses at all plots in the period from 1990 to 2015 have declined the most for lead (89\%), vanadium (85\%), chromium (78\%), iron (71\%), cadmium (69\%) and nickel (66\%), followed by zinc (21\%) and copper (14\%). Maps of heavy metal distribution (Fig. 2), clearly indicate that local pollution zones in Latvia are divided into the Liepāja ( $\mathrm{Zn}$, $\mathrm{V}, \mathrm{Pb}, \mathrm{Fe}, \mathrm{Cu}, \mathrm{Cd}, \mathrm{Cr}$ ), Ventspils ( $\mathrm{Fe}, \mathrm{V})$, Brocēni ( $\mathrm{Fe}, \mathrm{Zn}$, $\mathrm{Ni}, \mathrm{Cu})$, Riga ( $\mathrm{Cu}, \mathrm{Cr})$, Daugavpils ( $\mathrm{Cu}, \mathrm{Ni}, \mathrm{Fe}, \mathrm{Zn}, \mathrm{Cr})$, Mažeikiai $(\mathrm{V}, \mathrm{Ni})$ and Naujoji Akmene $(\mathrm{Cu}, \mathrm{Fe}, \mathrm{Ni})$ areas. There are three main factors that stand out, explaining some of the pollutants and their distribution tendencies: windblown dust, long-range transport of air pollution and local pollution sources (Harmens et al. 2015). The presence of some other factors also cannot be ruled out.

Notably, the most complex heavy metal pollution
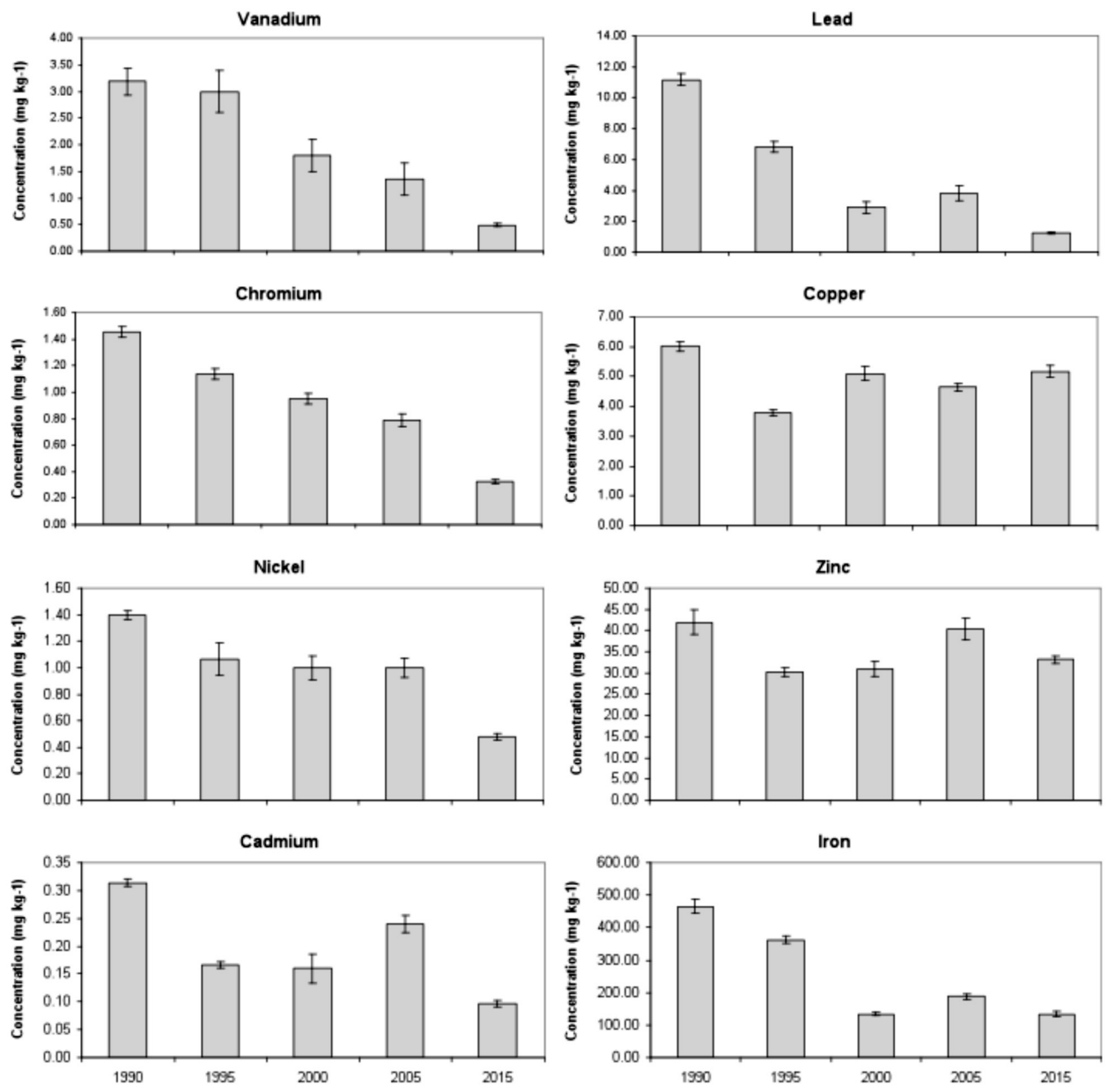

Fig. 4. Median heavy metal (V, Cr, $\mathrm{Ni}, \mathrm{Cd}, \mathrm{Pb}, \mathrm{Cu}, \mathrm{Zn}, \mathrm{Fe})$ concentrations $\left(\mathrm{mg} \mathrm{kg}^{-1}\right)$ in mosses in Latvia in five surveys from 1990 to 2015 $(1990,1995,2000,2005,2015)$. Standard errors are shown. 
is characteristic to the Liepāja area, mainly caused by the operations of metallurgy industries in Liepāja and long-range transport of pollution from Western Europe (Nikodemus, Brūmelis 1998, Nikodemus et al. 2004).

Decrease in $\mathrm{V}$ and $\mathrm{Ni}$ concentrations (Fig. 4) can be explained by the fact that many thermal power plant have substituted oil products with gas or biofuel (Nikodemus et al. 2004) that are more environmental friendly. Similar conclusions were made in Lithuania: when oil was used as fuel in the Naujoji Akmene plant, a higher pollution level of $\mathrm{Ni}$ was identified around it, and increased pollution with $\mathrm{V}$ was found close to the Alytus thermal power plant (Čeburnis et al. 1997). Kvietkus et al. (2011) also note that anthropogenic elements $(\mathrm{Pb}, \mathrm{Zn}, \mathrm{Cr}, \mathrm{Ni}, \mathrm{Cu}, \mathrm{Cd})$ have higher concentrations during the cold period, which is indicative of more intense operations of thermal power industry during the heating season. Compared to 2000 (Nikodemus et al.2004) and 2005 (Harmens et al.2008), the maximum V concentrations in moss near Ezere plot (Lithuania border) have decreased more than nine times. Previous mappings do not show increased $\mathrm{V}$ concentrations in moss near Riga (Nikodemus, Brūmelis 1998, Nikodemus et al. 2004), and this can be related to the switching from liquid fuel to gas in the Riga Thermal Power Plant 2 (TEC 2). Similarly to V, $\mathrm{Ni}$ can be related to the operations of the Mažeikiai Nafta oil refinery plant.

Lead concentration in moss in the vicinity of Liepāja in 2015 decreased 5.4 times when compared to 2005. This decrease might be related to the irregular operations of the most important environment polluter of that area - the metallurgy industry of Liepājas Metalurgs AS, as well as to the decrease in long-range transport of pollution from Western Europe. $\mathrm{Pb}$ concentration in moss depends on traffic intensity (Kösta, Liiv 2011). In addition, decrease of $\mathrm{Pb}$ concentrations could be related not only to the decline in the intensity of industrial manufacturing but also to the improved emission control not only in Latvia but also in entire Europe, as well as to the decrease of usage of $\mathrm{Pb}$ containing fuel and improvement of road transport quality (EEA 2012).

Copper is one of the heavy metals whose concentration in P. schreberi moss has not decreased during the last decade in Latvia. Oil products contain high concentrations of $\mathrm{Cu}$, and road transport, metallurgical industry and burning of fossil fuels also account for pollution with this heavy metal (Harmens et al. 2013). Moreover, for many years, pharmaceutical companies have been significant sources of $\mathrm{Cu}$ pollution in Latvia, especially in Olaine (Brūmelis, Nikodemus, 1993). Now, as shown in Figure 2C, the most significant sources of pollution are located in industrial cities of Latvia (Liepāja, Riga, Rēzekne, Daugavpils) as well as in Brocēni and Naujoji Akmene (cement industries). The locations of pollution sources have not changed when compared to the previous stages of heavy metal distribution mapping (Nikodemus et al. 2004).
Iron concentration in $P$. schreberi moss and its territorial distribution in Latvia is related to both natural and anthropogenic factors. Concentrations of elements of natural origin ( $\mathrm{Fe}$ and $\mathrm{Mn}$ ) were higher during the warm period (Kvietkus et al. 2011), and this is related to iron pollution entering the environment due to industry. In agricultural areas, in turn, the source of Fe pollution can be soil dust (Harmens et al. 2007). Fe concentration decrease in moss in Latvia can be explained by the change from oil and coal fuel to biofuel in thermal power plants and cogeneration stations (Central Statistical Bureau 2016) and from liquid fuel to gas in Riga TEC 2, as well as by the decrease of arable land areas (Silava 2016).

Increased $\mathrm{Cr}$ concentrations in moss in Latvia are focused around industrial cities: Liepāja, Olaine, Riga and Daugavpils. Generally, higher Cr levels are found in the southern part of Latvia (Fig. 2B). Starting with 1990, a steady decreasing tendency in $\mathrm{Cr}$ concentration in moss can be observed in the entire territory of Latvia and especially around Brocēni. Also around the Kunda Nordic Tsement AS cement industry in NE Estonia, the concentration of $\mathrm{Cr}$ has decreased by 59\% over the period of 1989-2008 (Kösta, Liiv 2011), while its concentration around the Latvian cement industry in Brocēni has decreased by $71 \%$ over the period from 1990 to 2005 and by $84 \%$ from 1990 to 2015. The decrease of $\mathrm{Cr}$ concentration can be explained by a rapid reduction in the operational intensity of heavy metallurgy and cement manufacture industries. Like $\mathrm{Cr}$, $\mathrm{Cd}$ is also widely used in heavy metallurgy industries (EEA 2012). Cd pollution has significantly decreased in Latvia and in entire Europe (Harmens et al. 2010).

Most metallurgical industries emit $\mathrm{Zn}$ in the atmosphere (Harmens et al. 2007); this is also the case in Latvia, around the Liepāja metallurgical industry in particular. In comparison with 2000, when the maximum $\mathrm{Zn}$ concentration in Latvia in the direct impact zone of the Liepāja metallurgical industry was $189.00 \mathrm{mg} \mathrm{kg}^{-1}$ (Nikodemus et al. 2004), by now the concentration of $\mathrm{Zn}$ in moss has dropped to $99.79 \mathrm{mg} \mathrm{kg}^{-1}$ - almost twice over the last 15 years. This drop is definitely related to the economic difficulties and irregular operations of Liepājas metalurgs AS.

On the European scale, the median N concentrations in 2005 and 2010 were $1.26 \%$ and $1.19 \%$ respectively (Harmens et al. 2013). According to our results, the median $\mathrm{N}$ concentration in 2015 was $1.13 \%$ (Table 1). This roughly corresponds to the background level in European countries.

The highest $\mathrm{N}$ concentrations are found in the southwestern part of Latvia, due to the long-range transboundary transport of pollution, as well as in the territories with intensive agriculture and areas close to industrial cities. Generally, mosses affected by canopy drip have higher $\mathrm{N}$ concentrations due to the higher $\mathrm{N}$ content in throughfall deposition (Skudnik et al.2014). Nitrogen presented a more diffuse spatial distribution in the entire area. 
Generally, when assessing the situation in Latvia, it can be noticed that the atmospheric pollution with heavy metals is not high and has a decreasing tendency at regional levels. At the same time, in the future, attention should be paid to local pollution sources in cities where bioindicators can be used for determining atmospheric pollution (Pīrāga et al. 2017).

The mapping results of heavy metal distribution in the atmosphere in Latvia in 2015 using P. schreberi moss confirmed its efficiency in atmospheric air quality change control. This method allows to determine not only spatial heavy metal and nitrogen distribution but also temporal changes.

\section{Acknowledgements}

The study was sponsored by the Administration of Latvian Environmental Protection Fund.

\section{References}

Silava. 2016. Gas emission (SEG) caused by the greenhouse effect of arable land and perennial grassland management and improvement of carbon dioxide $\left(\mathrm{CO}_{2}\right)$ attachment recording system, and development of corresponding methodological solutions. Review. 2016. Salaspils: Latvian Forestry Research Institute "Silava", Salaspils. /in Latvian/

Boquete M.T., Aboal J.R., Carballeira A., Fernández J.A. 2014. Effect of age on the heavy metal concentration in segments of Pseudoscleropodium purum and the biomonitoring of atmospheric deposition of metals. Atm. Environ. 86: 28-34.

Brūmelis G., Brown D.H., Nikodemus O., Tjarve D. 1999. The monitoring and risk assessment of $\mathrm{Zn}$ deposition around metal smelter in Latvia. Environ. Monit. Assess. 58: 201-212.

Brūmelis G., Nikodemus O. 1993. Heavy metal pollution in the pharmaceutical manufacturing centre of Olaine, Latvia. Proc. Latv. Acad. Sci. B 10: 57-59.

Brūmelis G., Nikodemus O. 1995. Biological monitoring in Latvia using moss and soil: Problems in the partitioning of anthropogenic and natural effects. In: Bioindicators of Environmental Health. SPB Academic Publishing, pp.123-132.

Central Statistical Bureau. 2016. Latvian Energy Balance 2015. http://www.csb.gov.lv/sites/default/files/nr_33_latvijas_ energobilance_2015_16_00_lv.pdf /in Latvian/

Čeburnis D., Rühling A., Kvietkus K. 1997. Extended study of atmospheric heavy metal deposition in Lithuania based on moss analysis. Environ. Monit. Assess. 47: 135-152.

Čeburnis D, Steinnes E, Kvietkus K. 1999. Estimation of metal uptake efficiencies from precipitation in mosses in Lithuania. Chemosphere 38: 445-455.

Dolıgowska S., Migaszewski Z.M. 2011. PAH concentrations in the moss species Hylocomium splendens (Hedw.) B.S.G. and Pleurozium schreberi (Brid.) Mitt. from the Kielce area (southcentral Poland). Ecotoxicol. Environ. Safety 74: 1636-1644.

European Environment Agency. 2012. European Union Emission Inventory Report 1990-2010 under the UNECE Convention on Long-range Transboundary Air Pollution (LRTAP). European Environment Agency Technical report No 8/2012. http://www.eea.europa.eu/publications/eu-emissioninventory-report-1990-2010.
Gałuszka A. 2007. Distribution patterns of PAHs and trace elements in mosses Hylocomium splendens (Hedw.) B.S.G. and Pleurozium schreberi (Brid.) Mitt. from different forest communities: A case study, south-central Poland. Chemosphere 67: 1415-1422.

Genoni P., Parco V., Santagostino A. 2000. Metal biomonitoring with mosses in the surroundings of an oil-fired plant in Italy. Chemosphere 41: 729-733.

Gerdol R., Bragazza L., Marchesini R., Alber R., Bonetti L., Lorenzoni G., Achilli M., Buffoni A., De Marco N., Franchi M., Pison S., Giaquinta S., Palmieri F., Spezzano P. 2000. Monitoring of heavy metal deposition in Northern Italy by moss analysis. Environ. Pollut. 108: 201-208.

González-Miqueo L., Elustondo D., Lasheras E., Santamaría JM. 2010. Use of native mosses as biomonitors of heavy metals and nitrogen deposition in the surroundings of two steel works. Chemosphere 78: 965-971.

Harmens H., Norris D.A., Cooper D.M., Mills G., Steinnes E., Kubin E., Thöni L., Aboal J.R., Alber R., Carballeira A., Coşkun M., De Temmerman L., Frolova M., González-Miqueo L., Jeran Z., Leblond S., Liiv S., Maňkovská B., Pesch R., Poikolainen J., Rühling Å., Santamaria J.M., Simonèiè P., Schröder W., Suchara I., Yurukova L., Zechmeister H.G. 2011. Nitrogen concentrations in mosses indicate the spatial distribution of atmospheric nitrogen deposition in Europe. Environ. Pollut. 159: 2852-2860.

Harmens H., Norris D.A., Koerber G.R., Buse A., Steinnes E., Rühling Å. 2007. Temporal trends in the concentration of arsenic, chromium, copper, iron, nickel, vanadium and zinc in mosses across Europe between 1990 and 2000. Atm. Environ. 41: 6673-6687.

Harmens H., Norris D., Mills G., the Participants of the moss survey. 2013. Heavy metals and nitrogen in mosses: spatial patterns in 2010/2011 and long-term temporal trends in Europe. ICP Vegetation Programme Coordination Centre, Centre for Ecology \& Hydrology, Bangor, UK, 63 pp.

Harmens H., Norris, D., the Participants of the moss survey. 2008. Spatial and Temporal Trends in Heavy Metal Accumulation in Mosses in Europe (1990-2005). ICP Vegetation Programme Coordination Centre, Centre for Ecology \& Hydrology, Bangor, UK., 51 pp.

Harmens H., Norris D.A., Sharps K., Mills G., Alber R., Aleksiayenak Y., Blum O., Cucu-Man S.-M., Dam M., De Temmerman L., Ene A., Fernández J.A., Martinez-Abaigar J., Frontasyeva M., Godzik B., Jeran Z., Lazo P., Leblond S., Liiv S., Magnússon S.H., Maňkovská B., Karlsson G. P., Piispanen J., Poikolainen J., Santamaria J.M., Skudnik M., Spiric Z., Stafilov T., Steinnes E., Stihi C., Suchara I., Thöni L., Todoran R., Yurukova L., Zechmeister H.G. 2015. Heavy metal and nitrogen concentrations in mosses are declining across Europe whilst some "hotspots" remain in 2010. Environ. Pollut. 200: 93-104.

Harmens H., Norris D.A., Steinnes E., Kubin E., Piispanen J., Alber R., Aleksiayenak Y., Blum O., Coşkun M., Dam M., De Temmerman L., Fernández J.A., Frolova M., Frontasyeva M., González-Miqueo L., Grodzińska K., Jeran Z., Korzekwa S., Krmar M., Kvietkus K., Leblond S., Liiv S., Magnússon S.H., Maňkovská B., Pesch R., Rühling A., Santamaria J.M., Schröder W., Spiric Z., Suchara I., Thöni L., Urumov V., Yurukova L., Zechmeister H.G. 2010. Mosses as biomonitors of atmospheric heavy metal deposition: Spatial patterns and temporal trends in Europe. Environ. Pollut. 158: 3144-3156. 
Harmens H., Schnyder E., Thöni L., Cooper D.M., Mills G., Leblond S., Mohr K., Poikolainen J., Santamaria J., Skudnik M., Zechmeister H. G., Lindroos A.-J., Hanus-Illnar A. 2014. Relationship between site-specific nitrogen concentrations in mosses and measured wet bulk atmospheric nitrogen deposition across Europe. Environ. Pollut. 194: 50-59.

ICP Vegetation. 2010. Heavy Metals in European Mosses: 2010 Survey. 2010. Monitoring Manual. International Cooperative Programme on Effects of Air Pollution on Natural Vegetation and Crops. ICP Vegetation Programme Coordination Centre, Centre for Ecology \& Hydrology, Bangor, UK, http:// icpvegetation.ceh.ac.uk.

Kayee P., Songphim W., Parkpein A. 2015. Using Thai native moss as bio-adsorbent for contaminated heavy metal in air. Procedia Social Behav. Sci. 197: 1037-1042.

Kosior G., Samecka-Cymerman A., Kolon K., Kempers A.J. 2010. Bioindication capacity of metal pollution of native and transplanted Pleurozium schreberi under various levels of pollution. Chemosphere 81: 321-326.

Kösta H., Liiv S. 2011. Spatial and temporal trends of heavy metal accumulation in mosses in Estonia. Ecol. Environ. 144: 133144.

Kvietkus K., Šakalys J., Valiulis D. 2011. Trends of atmospheric heavy metal deposition in Lithuania. Lithuanian J. Physics 51: 359-369.

Markert B, Herpin U, Berlekamp J, Oehlmann J, Grodzinska K, Mankovska B, Suchara I, Siewers U, Weckert V, Lieth H. 1996. A comparison of heavy metal deposition in selected Eastern European countries using the moss monitoring method, with a special emphasis on the 'Black Triangle'. Sci. Total Environ. 193: 85-100.

Migaszewski Z.M., Gałuszka A., Crock J.G., Lamothe P.J., Dołęgowska S. 2009. Interspecies and interregional comparisons of the chemistry of PAHs and trace elements in mosses Hylocomium splendens (Hedw.) B.S.G. and Pleurozium schreberi (Brid.) Mitt. from Poland and Alaska. Atm. Environ. 43: 1464-1473.

Nikodemus O., Brūmelis G. 1993. The effect of the Mažeikiai industry on concentrations of chemical elements in moss and forest soils. Latvijas Zinātñu Akadèmijas Vēstis B 9: 58-63. I in Latvian/

Nikodemus O., Brūmelis G. 1998. Monitoring of atmospheric heavy metal deposition in Latvia. Proc. Latv. Acad. Sci. B 52: 17-24.
Nikodemus O., Brūmelis G., Tabors G., Lapiņa L., Pope S. 2004. Monitoring of Air Pollution in Latvia Between 1990 and 2000 Using Moss. J. Atm. Chem. 49: 521-531.

Pīrāga D., Tabors G., Nikodemus O., Žìgure Z., Brūmelis G. 2017. Current content of selected pollutants in moss, humus, soil and bark and long-term radial growth of pine trees in the Mezaparks forest in Riga. Environ. Sci. Pollut. Res. 24: 1196411977.

Poikolainen J., Kubin E., Piispanen J., Karhu J. 2004. Atmospheric heavy metal deposition in Finland during 1985-2000 using mosses as bioindicators. Sci. Total Environ. 318: 171-185.

Rinne R.J.K., Mäkinen A.I. 1988. Regional and species variation in metal content of two woodland mosses Pleurozium schreberi and Hylocomium splendens in Finland and northern Norway. Silva Fennica 22: 89-97.

Ross H.B. 1990. On the use of mosses (Hylocomium splendens and Pleurozium schreberi) for estimating atmospheric trace metal deposition. Water Air Soil Pollut. 50: 63-76.

Rühling Å., Tyler G. 1973. Heavy metal deposition in Scandinavia. Water Air Soil Pollut. 2: 445-455.

Salemaa M., Derome J., Helmisaari H.-S., Nieminen T., VanhaMajamaa I. 2004. Element accumulation in boreal bryophytes, lichens and vascular plants exposed to heavy metal and sulfur deposition in Finland. Sci. Total Environ. 324: 141-160.

Skudnik M., Jeran Z., Batič F., Simončič P., Lojen S., Kastelec D. 2014. Influence of canopy drip on the indicative N, S and d $15 \mathrm{~N}$ content in moss Hypnum cupressiforme. Environ. Pollut. 190: 27-35.

Steinnes E., Rühling Å, Lippo H., Mäkinen A. 1997. Reference materials for large-scale metal deposition surveys. Accred. Qual. Assur. 2: 243-249.

Sucharová J., Suchara I. 2004. Current multi-element distribution in forest epigeic moss in the Czech Republic - a survey of the Czech national biomonitoring programme 2000. Chemosphere 57: 1389-1398.

Šakalys J., Kvietkus K., Sucharová J., Suchara I., Valiulis D. 2009. Changes in total concentrations and assessed background concentrations of heavy metals in moss in Lithuania and the Czech Republic between 1995 and 2005. Chemosphere 76: 91-97.

Zechmeister H. G., Hohenwallner D., Hanus-Illnar A., Hagendorfer H., Roder I., Riss A. 2008. Temporal patterns of metal deposition at various scales in Austria during the last two decades. Atm. Environ. 42: 1301-1309. 